\title{
Political Parties, Coalitions and Democracy
}

\author{
Jan-Erik Lane' ${ }^{1}$, Alexander M. Preker ${ }^{2 *}$ \\ ${ }^{1}$ UNIGE, Geneva, Switzerland \\ ${ }^{2}$ University of Freiburg, Freiburg, Germany \\ Email: janeklane@gmail.com
}

How to cite this paper: Lane, J.-E., \& Preker, A. M. (2018). Political Parties, Coalitions and Democracy. Open Journal of Political Science, 8, 447-466. https://doi.org/10.4236/ojps.2018.84029

Received: August 14, 2018

Accepted: October 22, 2018

Published: October 25, 2018

Copyright $\odot 2018$ by author and Scientific Research Publishing Inc. This work is licensed under the Creative Commons Attribution International License (CC BY 4.0).

http://creativecommons.org/licenses/by/4.0/

\begin{abstract}
The often heard call for other forms of democracy than the adversarial type is not realistic. MWCs and MSCs offer a peaceful mechanism for voting to handle social conflicts by means of political parties under the constraints of rule of law and the principal-agent interaction. Switzerland is the only consociational state today, but operating under heavy referenda restraints.
\end{abstract}

\section{Keywords}

Democracies, Coalitions, Two German States, Voting Power, Weber on the Political Party

\section{Introduction}

It is popular among scholars to speak about various types of democracy again, like after the Second World War. It is argued that competitive democracy or adversarial democracy has flaws enough to warrant searching for alternatives while respecting the rule of law principles of constitutional democracy.

In the social sciences, semantic deliberations often offer a route to increased clarity. Where there is fierce theory contestation and a lack of an established set of hypotheses for various domains of inquiry, the question of the usage of key terms may pay off in reducing theoretical confusion and word ambiguity. The term "democracy" comes readily to one's mind as a classic example of contending definitions of words.

An early example of a major sematic study in the social sciences was the UN sponsored inquiry into "democracy" by Norwegian philosopher Naess (1956). In reality, it was conducted by no one else than Stein Rokkan. Using Naess' methods of empirical semantics, a lot of distinctions were presented like true or real democracy.

We hear about unitary democracy (Mansbridge), negotiated democracy (Jo*responsible for the Banzhaf section. 
hansen), inclusive democracy (Gare) and consensus democracy (Lijphart) and ecological democracy. I will argue that these new theories bypass the insights of Riker (1962) that politics is much about value conflicts and that simple majority is an excellent peaceful mechanism for political parties to resolve societal clashes.

\section{Typology, Taxonomy and Classification}

When a phenomenon $\mathrm{X}$ is said to belong to type $\mathrm{T}$, then the reason can be that $\mathrm{X}$ has property $\mathrm{P}$ or a few properties $\mathrm{P} 1, \mathrm{P} 2, \ldots, \mathrm{PN}$. Or the reason can be that $\mathrm{X}$ is a member of a set $\mathrm{S}$, comprising all phenomena similar to $\mathrm{X}$. Thus, the $\mathrm{CH}$ is a consensus democracy due to its property of oversized governments and it has for quite some time been a member of a set of such democracies, like earlier the Austria plus Uruguay ("collegiado") and Lebanon.

In comparative social enquiry, it is essential to separate between property and set S. Given a property or a few properties, one may ask which units X1, X2, ..., $\mathrm{XN}$ satisfy the property(ies). Or one may proceed the other way around, asking for instance what, if any, are the common properties of Asian authoritarianism in China, South East Asia and the "Stans". The methods of comparison-see Pennings, Keman, \& Woldendorp (2006) - are useful whether one starts with P or S. One may come to realize that the set S is in reality two subsets S1 and S2 with only a few trivial common properties. Then it is relevant to speak of different combinations of properties $P$ in a typology.

In the social sciences, the match between $\mathrm{P}$ and $\mathrm{S}$ is often problematic, which is why one attempts to launch so-called pure types or ideal types. Pure type constructions have a complex of properties but are not true of any real life units. Max Weber liked to construct pure types in order to measure how close or far away real phenomena were. This conceptual strategy is not without risk, as one cannot be sure one has hit the essential mix of properties.

Political science lacks a parsimonious classification of constitutional democracies. There are presidential and semi-presidential democracy sub-sets. But how can one make divisions among the large set of parliamentary democracies? Too many properties P1, P2, ..., PN would result in complicated sets of cross-classifications without uniqueness and simplicity.

Is the well-known model of consensus democracy by Arend Lijphart an ideal-type for NON-BRITISH democracy, or is it taxonomy over all constitutional democracies? Sweden is said to be a consensus democracy (Lewin), India (Lijphart), Switzerland (Kriesi, Vatter), Germany (Schmidt)—is this a correct classification of the set of democracies? Let us start with the chief actors-political parties-and their coalitions, whether minimum sized (adversarial democracy) or oversized (consensus democracy). What do parties maximize?

\section{Nature of a Political Party: Weber}

Political parties can be recognized on the basis of their visible characteristics, viz.: formal organisation, electoral contestation, parliament representation and government participation, having at least 2 of these 4 features. But what is the 
objective of these actors, i.e. the people in the parties in a representative democracy? Max Weber answered in his realist perspective on humans: power (Weber, 1919, 2012; Michels, 1962; Katz \& Mair, 1995).

Weber (1978: 1395-1396) makes a number of theoretical comments on parties in a Parliamentary regime. He states again at one place: "Parties" reside in the sphere of power." But is the political party a means or an end and for whom? Given his realism, one would guess that power is the goal of parties, but he is much more nuanced.

Weber (1978: 1395-1396) lists five characteristics of a political party:

1) Parties are basically voluntary organizations;

2) Today the goal of the parties is vote-getting in an election for political positions or a voting body;

3) A hard core of interested members is directed by a leader or a group of notables; this core differs greatly in the degree of its hierarchical organization, yet is nowadays often bureaucratized.; it finances the party with the support of rich sponsors, economic interests, office seekers, or dues-paying members;

4) The hard core creates program and selects the candidates. Even in mass parties with very democratic constitutions, the voters and most of the rank and file members do not participate in the drafting of the program and the selection of the candidates,. By their very nature such parties develop a salaried officialdom or bureaucracies.

5) The voters exert influence to the extent that programs and candidates are adapted and selected according to their chances of receiving electoral support.

The Weber list of party properties is from "today", he writes i.e. Germany around 1918. What acute observations, still valid today, i.e. 100 years after. But his definition excludes parties in the so-called Second and Third World, which just shows that Weber was concerned with the modern democratic regimes. It had to have a representative dispensation with political parties of basically two types, viz.:

1) Parties "essentially organizations for job patronage, as they have been in the United States since the end of the great differences about the interpretation of the Constitution. In this case they are merely interested in putting their leader into the top position so that he can tum over state offices to his following ..."

2) "The party is primarily ideological (Weltanschauungs-partei) and intended to accomplish the realization of substantive political ideals. In relatively pure form this type was represented in Germany by the Catholic Center party of the eighteen-seventies and the Social Democrats before they became bureaucratized." Moreover:

"Parties are, therefore, only possible within groups that have an associational character, that is, some rational order arid a staff of persons available who are ready to enforce it. For parties aim precisely at influencing this staff, and if possible, to recruit from it party 'embers'." (Weber, 1978: pp. 904-906).

Yet, why do politicians create and support parties in the first place? One should avoid analysing political parties as unitary actors-reification or the fal- 
lacy of misplaced concreteness. They are nothing but a group of politicians (Dahl, 1957).

\section{The Party as Itself a Coalition: Minimising Transaction Costs}

Political parties are nothing but coalitions among individuals who wish to compete in open entry. Together they stand a better chance of gaining than going along alone. To act as a collective unit, they need some coherence of commitments-the ideology. The party program or platform makes it possible for the coalition of party members to campaign with a reasonably clear message that has some coherence in the views of supporters. On the other hand, the necessity of a political party for competing successfully constitutes a real hindrance for loners who would wish to enter but lacks a party affiliation.

Not even a charismatic person can in open entry alone. Some form of political party is necessary. To distinguish one group of political from another, these coalitions we can "parties" employ a variety of tools: ideology, slogans, labels, logos, etc. The coherence of a party is never 100 per cent, as infighting and factions often occur. Politicians interpret the vocabulary of the party differently, and splits can be very serious indeed.

The prevalence of political parties in open entry implies that party organisations with huge staff and resources enter the basic equation of remuneration $\mathrm{R}$ and value $\mathrm{V}$. One could argue that the remuneration $\mathrm{R}$ of the party staff should be the burden of the political elite or its followers, but one often encounters public mechanisms for the reimbursement of the costs of political parties, i.e. their $\mathrm{R}$ is taken from $\mathrm{V}$. The political party may be inclined to use whatever command it has over $\mathrm{V}$ to benefit especially themselves-see the literature on the political business cycle.

Partitocrazia involves a fierce struggle among various elite groups for remuneration and access to leadership position. It may degenerate into infighting to such an extent that the party in question cannot operate adequately. And it may make a political club ungovernable with huge costs for society.

In open entry political cubs, political parties or coalitions among leadership groups compete on the basis of promises and blame. The first strategy is basically what the parties claim they can do for the size of V:

- Higher economic growth;

- Investments in infrastructure;

- Improvements in public services;

- Better control of violence and crime, including terrorism now;

- More of income and wealth redistribution.

Are these promises credible? Could not the leadership of a club result in losses in V? Here is where the logic of political competition comes in. The second strategy is the blame, with a strong call for change. In open entry clubs, political competition should in principle be conducive to the maximisation of $\mathrm{V}$, given a 
modest R. However, the parties in competition may promise too much and blame unreasonable.

The principle of spoils (spolia) is essential to party government in open entry clubs. By winning an election, the party(ies) may employ state resources (jobs, contracts, assignments, etc.) to remunerate the party leaders for their effort to secure victory. In some countries, the costs of the political parties have been more or less entirely transferred to the state coffers by means of public support for them. Spoils, however, require electoral success.

\section{Party Coalitions in Government}

We face a methodological choice between two established frameworks:

1) Riker

In his Theory of Political Coalitions (1962), W. Riker suggested a parsimonious taxonomy for coalitions that still works today with some modifications for connectedness among players (de Swann):

a) Minimum winning coalition $(\mathrm{MWC})>51 \%$, if one players leaves, the coalition loses;

b) Minimum sized coalition (MSC) $>51 \%$, but there is no superfluous player;

c) Oversized coalition $>60 \%$ with superfluous player(s);

d) Grand coalition: encompassing, > 75\%.

And he derived a basic coalition principle-the size principle-to explain changes in coalitions. We shall see below that "grand coalition" in Germany can stand for a MWC between the two biggest parties on the Right and Left (Schmidt, 2015), meaning that it can be MWC but hardly MSC.

2) Lijphart

There are many sources for the content of the concept of consensus democracy, but they all give a complex of properties $\mathrm{P} 1, \mathrm{P} 2, \ldots, \mathrm{PN}$, including coalitions. This entails that we need to inquire into whether there is a set $S$ of countries that satisfy these properties, or some them. We look especially at the FRG.

$\mathrm{H1}$ : "concentration of executive power in single-party majority [MWC] cabinets versus executive power-sharing in broad [not MWC] multiparty coalitions." (MWC means "minimal winning coalition"; is the cabinet just barely large enough to control a parliamentary majority (51\%), or does the cabinet include more parties than it has to?)

Thus, it is an axiom: Consensus democracy does not harbor MWC or MSC. We check for the FRG.

FRG (Chancellors and coalitions).

Adenauer (MWC, MSC), Erhard (MWC, MSC), Kiesinger (MWC, MSC), Kiesinger (MWC, Oversized), Brandt (MWC, MSC), Schmidt (MWC, MSC), Kohl (MWC, MSC), Schroeder (MWC, MSC), Merkel (MWC, Oversized), Merkel (MWC, MSC).

Note: $\mathrm{MWC}=$ minimum winning coalition; $\mathrm{MSC}=$ minimum sized coalition

Source: Wiki Summary, 
https://en.wikipedia.org/wiki/List_of_Federal_Republic_of_Germany_governme nts

H1 satisfies CD? No.

$\mathrm{H} 2$ : "the executive (president or cabinet/prime minister) is dominant over the legislature vs. a legislative-executive balance of power."

The FRG practices what is called Kanzlersdemocratie that provides the chancellors about the same position as the British Premier.

$\mathrm{H} 2$ satisfies $\mathrm{CD}$ ? No.

H3: "two-party vs. multiparty system. (This is partly a function of electoral rules": pluralistic first-past-the-post electoral rules (which lead to disproportionate results) vs. proportional representation (PR).

H4:"pluralist (i.e. atomistic) interest groups vs. “corporatist' interest group systems aimed at compromise and concertation."

$\mathrm{H} 3$ and $\mathrm{H} 4$ satisfy CD, as Germany has PR and "drittelparitaet."

H5: "unitary vs. federal/decentralized structure."

H6: "unicameral vs. bicameral legislature (with two "equally strong but differently constituted houses')."

H7: "flexible, easily amended (or non-existent) constitutions vs. rigid, supermajority-amended constitutions."

H8: "legislatures determine constitutionality of own legislation vs. judicial review of constitutionality by an independent court."

H9: "executive control of central bank vs. central bank independence."

H5-H9 satisfy CD, as German constitutionalism has been built strongly with numerous restraints.

Consensus democracy comprises as model so many properties that no one set satisfies them all. When two most essential properties are lacking, how to characterize a case? If one ranks the properties above in terms of relevance, then clearly $\mathrm{H} 1$ and $\mathrm{H} 2$ come on top.

As events unfold in real life, a pure or ideal type may lose all connection with reality, making it more or less useless. I would argue that Lijphart's model of Westminster democracy (1985) has suffered this fate, but on the other his other ideal type of consensus democracy seems still relevant. First, "Westminster" as a proper noun and not all a theoretical term cannot be used properly in abstract taxonomy. Second, the changes in the UK have been so far-reaching that it no longer harbours the pure type of a centralized democratic regime-devolution: Scotland is more autonomous than German Laender. Of course, issues in the UK are complex and there are constitutional documents with even a little legal review (Lewin, 1998; Lijphart, 2012). Third, it may not survive the Brexit disaster that is now unfolding.

Lijphart's classification is not acceptable from the point of view philosophy of science, i.e. exclusiveness, uniqueness, simplicity. Too many, maybe all (!) democracies fall in both sub-sets-not allowed. Moreover, I am somewhat baffled by the theory of prominent professor Manfred Schmidt at UNI Heidelberg, appointed as the best in Deutschland, saying that the German democracy is basi- 
cally a consociational (consensus).Writing about "The Grand Coalition" state, Schmidt concludes an excellent overview of the FRG:

This is part of a more general message to be derived from the political institutions in Germany. It is almost impossible in the Federal Republic of Germany not to be governed by a grand coalition of federal government and state governments and a grand coalition of the major established parties-whether hidden or formal. Diverging majorities in the Lower House and the Upper House intensify this requirement. Particularly during periods in which formal coalitions have been formed between the CDU-CSU and the SPD, but also in periods of non-oversized coalitions and diverging majorities in the Bundestag and the Bundesrat, the Federal Republic of Germany can be regarded as the embodiment of the Grand Coalition State, a German-style consociational democracy.

https://www.uni-heidelberg.de/md/politik/personal/schmidt/schmidt_grand coalition_state_4th_edition.pdf, page 36 (February 5, 2015) (Schmidt, 2003, 2005; Vatter, 2009).

This is, I fear, flawed, as most governments are minimum sized a la Riker-also the "grand coalitions". One gets the impression that grand coalition is not distinguished from oversized coalition. The present Merkel government fits the size principle and has nothing to do with a German style consociationalism. CDU + CSU together with SDP just maximized power. Which, then, are the constraints upon parties?

\section{The Principal-Agent Restraint}

If Weber was correct about political parties maximizing power, then what restrains them from authoritarian behavior, like in so many dictatorships? The first source of constraints is the rule of law regime in a constitutional democracy. The second source of constraint is the principal-agent nature of the interaction between party and supporter. The capacity to shift to another party holds the party down on a carpet that can be pulled from underneath in any election. The number of party switchers may reach $50 \%$ in earth quake elections.

\section{Maximising Party Power: Banzhaf}

Political power under a regime with party government in a multi-party system derives from the capacity of parties to enter into winning coalitions, either ad hoc in relation to the voting on decision issues in Parliament, or as a permanent coalition government. The Banzhaf model of coordination in n-person games offers a method to estimate this form of political power, focusing upon coalitions. In short, the Banzhaf model measures the capacity of a party being successful in contributing to the success of a coalition in representative assemblies.

Parliament makes a huge number of decisions concerning for instance government formation and support, the budget and taxation as well as regulation in the form of legislation and oversight. Under party government, the actors in collective decisions are the political parties that tend to vote with one voice, based 
on their differential number of mandates. Both the constitutional rules of decision-making and the strategy of coalition formation are decisive for the outcomes of parliamentary decision-making.

Most decisions in Parliament require simple majorities, which is why a minimum winning coalition is enough. Sometimes certain decisions of constitutional relevance are singled out requiring a heavier support or qualified majority-see Wicksell below. To prevail, a winning coalition would then have to be oversized. In the normal business of government, simple majority (MWC or MSC) suffices in most parliamentary countries.

A coalition that is minimum winning does not need to be a minimum sized coalition. Actually, coalitions may be of many kinds, but the essential thing is that they win in voting (Riker, 1962). Coalitions may be temporary, focusing upon one voting sequence, or they may be permanent over an election period, such as for instance four years. Government coalitions are formed for the purpose of exercising power over a longer period, but government coalitions may break-up prematurely, leading either to a new government or to new elections (De Swaan, 1973; Downs, 1968; Bergman, 1995).

A political party maximizes its voting power by actively participating in the formation of coalitions (Laver, 1998; Shepsle, 2003). If it enters a government coalition, then it shares the voting power of the government with its governing partners. It may also exercise voting power by participating in temporary coalitions that achieve the minimum-winning format. Political power is mainly exercised through the capacity to influence voting in the national assembly. For instance, the election system returns the political parties to the German "Reichstag" or the Austrian "Nationalrat" roughly according to a numerical size that is decided by the election rules (electoral fairness), giving a certain voting support among the electorate.

\section{Banzhaf Power: Ex Ante and Ex Post}

$\mathrm{N}$-person games have no equilibria, which is why power indices have been launched. The literature is highly theoretical (Shapley \& Shubik, 1954; Banzhaf, 1968; Felsenthal \& Machover, 1998; Holler \& Illing, 2006; Holler \& Owen, 2001; Fara, Leech, \& Salles, 2014; Leech, 2002, 2012), with rather few empirical applications except some international bodies. Here, we try the national Parliament.

We distinguish between two parliamentary situations: a majority coalition and a minority coalition. In the first situation, the added Banzhaf power scores of government parties equal always 1 . This is a value equally shared by the coalition parties in same proportions, no matter how many seats the party may have won-threat power of quitting. In the second situation, the government Banzhaf power score is always smaller than 1 . Other parliamentary actors will receive Banzhaf points as well, since the voting power of the government is shared with some other parliamentary actor(s).

One may further calculate Banzhaf scores for every legislative period and 
weighted for every single year = modified aggregation. In the first step, the seats and the Banzhaf scores ex ante and ex post government formation are aggregated over time. In a second step, the data is modified by considering only those years, when the parties actually were in parliament or, as the case may be, in power.

According to the voting power scores measured by the Banzhaf approach, it is then most illuminating to look at the differences between the parties' share of seats in the parliamentary assembly and the share of voting power ex ante and ex post government formation. It can be shown how both the parties' influenceand voting-power can be different from the size of seats they hold in parliament and why some parties dominate the political game, whereas others do not play a big role despite their relative strength (Felsenthal \& Machover, 2005: p. 491).

To model voting in a national parliament, we will use cooperative game theory, or more specific, n-person games Here, we have the so-called simple games with two outcomes: win or lose. Given a proposition (bill, budget items, etc.), the players form either supporting or opposing coalitions. The total value the game, the payoff, is subsequently assigned to the winning coalition, while the losing coalition gets nothing. Since win or lose are the only outcomes of such voting games, we simplify the calculations by normalizing the payoff to 1 and 0 , hence the notion of a simple game. We calculate three voting power measures:

- Scores for single parliamentarians;

- Scores for the entire party before government formation-ex ante;

- Scores for the whole party after government formation-ex post.

\section{Examples: The Two German States}

When comparing party government in Germany and Austria before and after the fascist regimes, one can note the great similarity in terms of both political culture and political institutions (Rudzio, 2011; Pelinka, 2004):

- Parliamentarism: Representative government with the focus upon the chancellor;

- Federalism: Decentralized polity although with considerable competences at the centre;

- Election system: PR system employing alternative schemes delivering a rather high degree of proportionality between votes and seats, generally speaking;

- The decision-making process: An influential committee system and since the after war years also a high degree of (neo)corporatism (Siaroff, 1999).

Also the mass media systems of both countries developed similarly, as their important broadcast stations are mainly based on public law until this day. Focussing these similarities as well as the fact, that both, the German and the Austrian party systems have developed along resembling societal cleavages in the electorate over the last 90 years (Lipset \& Rokkan, 1967) and as systems of "moderate polarized pluralism" (Sartori, 1976), one has to ask, why the logic of party government has tended to be rather different in these two countries-with 
the political left dominating the Austrian and the political right dominating the German system of government. That's why we compare the two countries' party systems out of a most similar case research design. The analysis is made by using the parliamentary shares of seats in the national assemblies of Austria and Germany, compiled by national authorities. The data is covering the periods from 1919-33 in the Weimar republic and from 1949-2012 in the FRG as well as Austria during the $1^{\text {st }}$ republic $1919-1933$ and the $2^{\text {nd }}$ republic (1945-2012). The Nazi-period in both countries is left out of consideration.

\section{Weimar Republic}

The average situation of power distribution in the Weimar Republic from 1919-1933 is the following: It was especially the smaller parties and the right wing parties, which often joined government, and which were able to increase their voting- and influence power compared to both their share of seats and their ex ante government status.

The deviations from strict proportionality: DDP and BVP had larger influence- and voting power compared to their share of seats (DDP +6.7 percent, BVP +5.3 percent). Larger conservative parties, which frequently joined government, i.e. Zentrum and DVP, were also expanding their voting power by joining one or more of the mostly minority governments in the Weimar republic. Thereby the (here: external) coalitions can be seen as a latchkey to wield power. They can make minority or majority governments winning. In particular between 1923 and 1929 this was an aim, which was successfully followed by DVP's Gustav Stresemann.

Although the Weimar governments often were minority governments, the governing parties had significantly more voting power than they were entitled to, when taking the governmental share of mandates as a basis. This corresponds to the high fragmentation rate of the party system and provides another and new explanation for the appearance of the governments existing during this period and for the dominance of these parties.

Social democrats (SPD) or the communist party (KPD) were often unable to transform their outstanding mandate strength into effective influence or voting power ex post government formation. Although the Social democrats regularly were the largest party in parliament and their ex ante Banzhaf score is greater than their relative mandate strength, they only rarely joined government due to missing coalition options from the mid-1920s on. This is a phenomenon, which is also reflected by the social democratic loss of power from the ex ante to the ex post stage of government formation.

The nationalist DNVP, often supported by one of the (minority) governments, is different in comparison to the governing parties characterized by nearly constantly (high) ex ante and ex post Banzhaf scores and shows only a small loss of its relative proportion of seats to its power position ex ante government formation-a feature in common with other opposition parties. 
One could state that the political centre and the political right is overrepresented both ex ante and ex post government formation, whereas the political left parties, especially the social democrats, are clearly underrepresented in comparison to their relative mandate strength (Table 1).

FRG

Looking at the party systems at first glance, the findings for the FRG are totally different to those in the Weimar republic: after the first consolidating years with a multi-party system (Table 2), the German party system was condensed to a 2.5 party system (Poguntke, 1999). From then on, it was characterized by two "catch all" parties (Kierchheimer, 1965) on the one hand, CDU respectively CSU and SPD, and by the FDP as a 0.5 "pivotal" party (Keman, 1994) on the other hand. This setting held for nearly 30 years. However, when looking at the distribution of power, measured by the Penrose-Banzhaf-Coleman-approach, the findings are similar to those in the Weimar republic: again, the political left is underrepresented.

Only the liberal FDP can enlarge its power compared to its relative mandate strength. In turn, the Christian democratic CDU, respectively CSU, or "Union" for short, in turn, is despite small losses, only able to score constantly high Banzhaf points ex ante and ex post government formation. Still, with exception of the Brandt-and Schmidt-and Schröder-years, the FRG often had a Christian democratic majority coalition regime with the FDP taking a very powerful position, both due to its pivotal status and its therewith associated status as the longest lasting governmental party. Consequently, the FDP (+28 percent) and to a smaller amount also the Greens ( +4.6 percent), are the only parties in sixty years of FRG, to receive a positive value ex post government formation, when looking at the deviations from strict proportionality.

Concerning SPD's power scores, the Social democrats are often unable to transform their often distinctive mandate strength into effective influence or voting power ex post in government formation. Although they receive large allocations of seats, they have comparatively little power to win voting. Therefore, their lack of power ex post government formation is also much bigger (-18.1 percent) than the Christian democratic one ( -9.5 percent).

The weak position of the social democrats in the FRG is a political entity similar to that in the Weimar republic and, as a result, is valid despite the fractionalization of the federal German party system from a 2.5 party system to a polarized four, respectively five, party system during the last two or three decades (Rudzio, 2011). Reason: it is true that these changes also had influence on the distribution of power in parliament, but it was especially the left side of the party system which changed its shape

The SPD has indeed had the most coalition options from all relevant parties (Korte \& Fröhlich, 2004), but it also has one of the most different bargaining positions because of its lack of power. This is true not only adverse the smaller parties and when accounting ideology adverse the Greens, but also compared to the 
Table 1. Banzhaf Power distribution in the Weimar Republic 1919-1933.

\begin{tabular}{|c|c|c|c|}
\hline Party & & Modified aggregation & $\begin{array}{c}\text { Deviations from strict } \\
\text { proportionality (power-seats) }\end{array}$ \\
\hline \multirow[t]{3}{*}{ SPD } & seats (rel.) & 0.254736842 & \\
\hline & ex ante & 0.291411 & 0.0366742 \\
\hline & ex post & 0.179639259 & -0.0750976 \\
\hline U SPD & seats (rel.) & 0.154 & \\
\hline \multirow[t]{2}{*}{$(1919-1924)$} & ex ante & 0.139715 & -0.014285 \\
\hline & ex post & 0.1057972 & -0.0482028 \\
\hline \multirow[t]{3}{*}{ DNVP } & seats (rel.) & 0.138947368 & \\
\hline & ex ante & 0.126354053 & -0.0125933 \\
\hline & ex post & 0.113363011 & -0.0255843 \\
\hline \multirow[t]{3}{*}{ Zentrum } & seats (rel.) & 0.139635857 & \\
\hline & ex ante & 0.129780053 & -0.0098558 \\
\hline & ex post & 0.155244942 & 0.0156091 \\
\hline \multirow[t]{3}{*}{ BVP } & seats (rel.) & 0.037010234 & \\
\hline & ex ante & 0.034639444 & -0.0023708 \\
\hline & ex post & 0.090371939 & 0.0533617 \\
\hline \multirow[t]{3}{*}{ DVP } & seats (rel.) & 0.084253906 & \\
\hline & ex ante & 0.077607053 & -0.0066469 \\
\hline & ex post & 0.136149469 & 0.0518955 \\
\hline \multirow[t]{3}{*}{ DDP } & seats (rel.) & 0.058270387 & \\
\hline & ex ante & 0.052078947 & -0.00619144 \\
\hline & ex post & 0.124839478 & 0.066569091 \\
\hline NSDAP & seats (rel.) & 0.132896772 & \\
\hline \multirow[t]{2}{*}{ (1924-1933) } & ex ante & 0.148824857 & 0.015928085 \\
\hline & ex post & 0.116784334 & -0.016112438 \\
\hline Wirtschafts- & seats (rel.) & 0.024752883 & \\
\hline \multirow[t]{2}{*}{ partei } & ex ante & 0.023595211 & -0.001157672 \\
\hline & ex post & 0.029837938 & 0.005085055 \\
\hline \multirow[t]{3}{*}{ KPD } & seats (rel.) & 0.096936858 & \\
\hline & ex ante & 0.094663278 & -0.00227358 \\
\hline & ex post & 0.045465496 & -0.051471362 \\
\hline Dt.-Hannov. & seats (rel.) & 0.006994286 & \\
\hline \multirow[t]{2}{*}{ Partei } & ex ante & 0.006280333 & -0.000713953 \\
\hline & ex post & 0.001587514 & -0.005406772 \\
\hline Christl.-nat. & seats (rel.) & 0.020770765 & \\
\hline \multirow[t]{2}{*}{ Landvolk (1924-1933) } & ex ante & 0.018560071 & -0.002210694 \\
\hline & ex post & 0.012855946 & -0.007914819 \\
\hline CSVD & seats (rel.) & 0.015807965 & \\
\hline
\end{tabular}




\section{Continued}

\begin{tabular}{cccc}
\hline (1930-1933) & ex ante & 0.014741333 & -0.001066632 \\
& ex post & 0.013180917 & -0.002627048 \\
Konservative & seats (rel.) & 0.001299827 & \\
Volkspartei & ex ante & 0.0034224 & 0.002122573 \\
$(1930-1932)$ & ex post & 0.013798129 & 0.012498302 \\
Deutsche & seats (rel.) & 0.010404347 & \\
Bauernpartei & ex ante & 0.008974556 & -0.001429791 \\
(1928-33) & ex post & 0.003109667 & -0.00729468 \\
Others & seats (rel.) & 0.006491473 & \\
& ex ante & 0.00438 & -0.002111473 \\
& ex post & 0.001472844 & -0.005018629 \\
\hline
\end{tabular}

Abbr.: SPD = Sozialdemokratische Partei Deutschlands (social democratic); U SPD = Unabhängige Sozialdemokratische Partei Deutschlands (independent, socialist); DNVP = Deutschnationale Volkspartei (nationalist, conservative); Zentrum = Center party (catholic); BVP = Bayerische Volkspartei (Bavarian, conservative); DVP = Deutsche Volkspartei (liberal); DDP = Deutsche Demokratische Partei (social liberal); NSDAP $=$ Nationalsozialistische Deutsche Arbeiterpartei; Wirtschaftspartei $=$ liberals; KPD $=$ Kommunistische Partei Deutschlands (communists); Deutsch-Hannoversche Partei (local conservative party); Christl.-nat. Landvolk = Christlich-Nationale Bauern- und Landvolkpartei (agrarian, conservative); CSVD $=$ Christlich sozialer Volksdienst (protestant conservative); Konservative Volkspartei $=$ small conservative party; Deutsche Bauernpartei (agrarian).

Table 2. Banzhaf power distribution in the FRG 1949-2012.

\begin{tabular}{|c|c|c|c|}
\hline Party & & $\begin{array}{l}\text { Modified } \\
\text { aggregation }\end{array}$ & $\begin{array}{l}\text { Deviations from strict } \\
\text { proportionality (power-seats) }\end{array}$ \\
\hline \multirow[t]{3}{*}{$\mathrm{CDU} / \mathrm{CSU}$} & seats (rel.) & 0.52482205 & \\
\hline & ex ante & 0.501040618 & -0.023781432 \\
\hline & ex post & 0.429696945 & -0.095125105 \\
\hline \multirow[t]{3}{*}{ SPD } & seats (rel.) & 0.435363492 & \\
\hline & ex ante & 0.301324545 & -0.134038947 \\
\hline & ex post & 0.254545455 & -0.180818037 \\
\hline \multirow[t]{3}{*}{ FDP } & seats (rel.) & 0.111550297 & \\
\hline & ex ante & 0.242562455 & 0.131012158 \\
\hline & ex post & 0.395151491 & 0.283601194 \\
\hline \multirow[t]{3}{*}{ Grüne (since 1983) } & seats (rel.) & 0.070312448 & \\
\hline & ex ante & 0.153269967 & 0.082957519 \\
\hline & ex post & 0.116666667 & 0.046354219 \\
\hline PDS/ & seats (rel.) & 0.055674471 & \\
\hline Linkspartei.PDS/ & ex ante & 0.072640727 & 0.016966256 \\
\hline Die Linke (since 1991) & ex post & 0.000000000 & -0.055674471 \\
\hline Others & seats (rel.) & 0.01402697 & \\
\hline \multirow[t]{2}{*}{$(1949-61)$} & ex ante & 0.01501596 & 0.00098899 \\
\hline & ex post & 0.01301044 & -0.00101653 \\
\hline
\end{tabular}

Abbr.: CDU/CSU $=$ Christdemokratische Partei Deutschlands/Christlichsoziale Partei Bayerns (Christian democratic); SPD = Sozialdemokratische Partei Deutschlands (Social democratic); FDP = Freie Demokratische Partei (liberal); Grüne (ecological); PDS = Partei des demokratisches Sozialismus, Linkspartei.PDS, Die Linke (left socialist). 
Christian democratic Union.

This argument is also supported by the Banzhaf numbers of especially the Greens and Die Linke-at least ex ante government formation, since the latter one is still regarded as "regierungsunfähig" (incapable of governing) by the other four parties. Furthermore, this is a situation, which could in future sharpen and lead to more frequent Grand coalitions, if classifying the uprising Pirate Party as a left one. Power has increased though rather significantly for the Social democrats lately due to the coalitions with CDU + CSU.

These constructed scores can reflect a realistic picture of the existing power structures in a country's parliament and government across time. This especially becomes clear, if looking at the FRG, for example. Firstly Greens and Left Socialists appeared in the party system in the 1980s/90s. Taking their Banzhaf points from 1949 onwards into account would tamper the results. The same objection could be made, when considering, that for example other parties besides CDU/CSU, SPD and FDP competed only in the first years of the early FRG. Furthermore, reunification greatly changed the build-up of the Bundestag (e.g. the number of parliamentarians).

\section{First Austrian Republic (1919-1933)}

Turning towards Austria, the picture has to be drawn less distinctive: when looking at the first republic, the parties standing politically right were (even heavily) overpowered in comparison to their relative share of seats. On the other hand, in the second republic (1945-today), it is, contrarily, both the Austrian social democrats (SPÖ) and the Christian democratic ÖVP, who are able to enlarge voting- and influence power from the ex ante to the ex post stage of government formation, whereas different to the German system smaller parties (FPÖ, greens or BZÖ) only play a minor role in parliament and government.

In the interwar period, after the constitutional assembly in 1918, mainly three political blocks marked the Austrian party system: a socialist (SDAP), a Christian-catholic (Christlichsoziale) and a German nationalist party group, including some smaller parties (Pelinka, 2004: p. 535). However, as shown by the Banzhaf power distribution ex ante and ex post government formation, it was the Christian social party and the smaller German nationalist party group, which were participating regularly in government, neglected the two grand coalition years from SDAP and Christlich soziale until the constitution written by Hans Kelsen was established in 1920.

SDAP is also heavily underrepresented over the years, compared to its relative share of seats ( -25.9 per cent). The German nationalist party group was extremely overpowered (+31 per cent) in relation to its mandate strength it obtained in the elections. Although the German nationalist predominance increased over time, both the agrarian Landbund, as well as the paramilitary Heimatbund/Heimwehr formed as secessions from Christlichsoziale and Deutschnationale. However, these new-formed parties could not gain any noteworthy 
parliamentary power. The German nationalist party group stayed powerful and the Heimwehr especially made its political marks rather outside of parliament $-\mathrm{a}$ fact, which is reflected by it's both relatively small share of seats and its even smaller Banzhaf power index scores.

Summing up, it can be stated that in the first Austrian republic it was the right wing parties being (here even heavily) overpowered once more. This situation can partly also explain the politically smooth change from Austrian parliamentarism to Austrian fascism by Dollfuss in 1933-34 and to the "Anschluss" to Nazi-Germany in 1938-the SDAP in terms of parliamentary power, literally speaking, was powerless (Table 3 ).

\section{Second Austrian Republic (1945-2012)}

When analysing the political system of Germany after 1949, the FRG is often characterized as "The Grand Coalition State" (Schmidt, 1996). This institutional characterization of the political process, based on the politics in the federal system, is more true for Austria, comparing the number of grand coalitions, Austria (10) and not Germany (2). The here computed Banzhaf numbers for the parties

Table 3. Banzhaf power distribution in Austria 1919-1933 ( $1^{\text {st }}$ Republic).

\begin{tabular}{|c|c|c|c|}
\hline Party & & $\begin{array}{c}\text { Modified } \\
\text { aggregation }\end{array}$ & $\begin{array}{l}\text { Deviations from strict proportionality } \\
\text { (power-seats) modified aggregation }\end{array}$ \\
\hline \multirow[t]{3}{*}{ SDAP } & seats (rel.) & 0.326533333 & \\
\hline & ex ante & 0.333333333 & 0.0068 \\
\hline & ex post & 0.066666673 & -0.259866666 \\
\hline \multirow[t]{3}{*}{ Christlichsoziale } & seats (rel.) & 0.462751467 & \\
\hline & ex ante & 0.333333333 & -0.129418134 \\
\hline & ex post & 0.466666666 & 0.003915199 \\
\hline \multirow[t]{3}{*}{ Deutschnationale } & seats (rel.) & 0.13902 & \\
\hline & ex ante & 0.3333333 & 0.1943133 \\
\hline & ex post & 0.4499999967 & 0.310979967 \\
\hline \multirow[t]{3}{*}{ Landbund } & seats (rel.) & 0.14 & \\
\hline & ex ante & 0 & -0.14 \\
\hline & ex post & 0 & -0.14 \\
\hline \multirow[t]{3}{*}{ Heimatbund/Heimwehr } & seats (rel.) & 0.04424 & \\
\hline & ex ante & 0 & -0.04424 \\
\hline & ex post & 0.01777767 & -0.02646233 \\
\hline \multirow[t]{3}{*}{ Others } & seats (rel.) & 0.012 & \\
\hline & ex ante & 0 & -0.012 \\
\hline & ex post & 0 & -0.012 \\
\hline
\end{tabular}

Abbr.: SDAP = Sozialdemokratische Arbeiterpartei (social democratic); Christlichsoziale = Christlichsoziale Partei (christian-conservative); Deutschnationle = Deutsch-Nationale Bewegung (nationalist); Landbund (agrarian); Heimatbund/Heimwehr (paramilitary, nationalist). 
ex post government formation in Austria do clearly document this: in general, it is only the two catch all parties increasing their power by forming frequently governments together (SPÖ +42 per cent; ÖVP +27 per cent). When looking at the actual political situation in Austria, these findings appear to be valid, despite the countries' PR-election system and albeit the meanwhile establishment of newer types of coalition governments or the rise of smaller parties such as the Greens, the Liberals or the nationalist BZÖ. A grand coalition again ruled Austria since 2007 up to 3017 (Table 4).

Like the German system, the Austrian party system after 1945 was characterized for a long time by a 2.5 party system, existing out of SPÖ, ÖVP and the smaller FPÖ. Different to Germany however, the Austrian FPÖ never reached a

Table 4. Banzhaf power distribution in Austria after 1945 ( $2^{\text {nd }}$ Republic).

\begin{tabular}{|c|c|c|c|}
\hline Party & & $\begin{array}{c}\text { Modified } \\
\text { aggregation }\end{array}$ & $\begin{array}{c}\text { Deviations from strict } \\
\text { proportionality (power-seats) }\end{array}$ \\
\hline \multirow[t]{3}{*}{ KPÖ (1945-1959) } & seats (rel.) & 0.024675318 & \\
\hline & ex ante & 0.035714293 & 0.011038975 \\
\hline & ex post & 0 & -0.24675318 \\
\hline \multirow[t]{3}{*}{ Greens (since 1986) } & seats (rel.) & 0.074190836 & \\
\hline & ex ante & 0.058608031 & -0.015582805 \\
\hline & ex post & 0 & -0.074190836 \\
\hline \multirow[t]{3}{*}{ SPÖ } & seats (rel.) & 0.433602479 & \\
\hline & ex ante & 0.391257975 & -0.042344504 \\
\hline & ex post & 0.475124378 & 0.041521899 \\
\hline \multirow[t]{3}{*}{ ÖVP } & seats (rel.) & 0.418770529 & \\
\hline & ex ante & 0.366382331 & -0.052388198 \\
\hline & ex post & 0.445273631 & 0.026503102 \\
\hline \multirow[t]{3}{*}{ VdU/FPÖ (since 1949) } & seats (rel.) & 0.104511154 & \\
\hline & ex ante & 0.212018132 & 0.107506978 \\
\hline & ex post & 0.084656084 & -0.01985507 \\
\hline $\begin{array}{l}\text { Liberales Forum } \\
(1994-99) \text { Liberales }\end{array}$ & seats (rel.) & 0.055737705 & \\
\hline \multirow[t]{2}{*}{$(1994-2002)$} & ex ante & 0 & -0.055737705 \\
\hline & ex post & 0 & -0.055737705 \\
\hline \multirow[t]{3}{*}{ BZÖ (since 2006) } & seats (rel.) & 0.089253188 & \\
\hline & ex ante & 0.142857 & 0.053603812 \\
\hline & ex post & 0 & -0.089253188 \\
\hline
\end{tabular}

Abbr: KPÖ = Kommunistische Partei Österreichs (communistic), Greens= Grünen - Die grüne Alternative (ecological); SPÖ = Sozialdemokratische Partei Österreichs (social democratic); ÖVP = Österreichische Volkspartei (Christian democratic); VdU/FPÖ = Verband der Unabhängigen (1945-55)/since 1955: Freiheitliche Partei Österreichs (right-wing-demagogic, populist); Liberales Forum (liberal); BZÖ = Bündnis Zukunft Österreichs (nationalist-right-wing demagogic, economically liberal). 
"pivotal" status in the party system as the FDP did in Germany. The reason for this political entity, which clearly is shown by a even negative balance from FPÖ's ex post Banzhaf power points vice versa the parties' relative share of seats $(-0.01985507)$, is simple: the party's ability to govern is small due to its right wing and demagogic ideology (Pelinka, 2002: p. 283).

In contrast to Germany, it is in Austria not the political left, which is underrepresented. In contrast, especially the social democrats can enlarge their parliamentary power by joining government. Due to SPÖ’s slightly higher ex ante Banzhaf score and its therewith slightly better bargaining position in parliament, the second Austrian republic was for a much longer period ruled by social democratic chancellors (nearly 40 years) than the FRG (21 years).

\section{Conclusion}

Economists (Wicksell, Buchanan) and political scientists (Lijphart, Mansbridge) have argued that adversarial politics is not the best form of democracy. It is too narrow in its typical coalition making, especially when the MWC is also MSC. Yet, if politics is mostly about conflicts and political parties maximise power, then Riker was correct, with some modifications (de Swann). Today there is only ONE consensus democracy- $\mathrm{CH}-$ but even it does not fit the pure type of $\mathrm{CD}$ due to the enormous amounts of referenda that are MWC and MSC.

\section{Conflicts of Interest}

The authors declare no conflicts of interest regarding the publication of this paper.

\section{References}

Banzhaf III, J. F. (1965). Weighted Voting Doesn't Work: A Mathematical Analysis. Rutgers Law Review, 19, 317-343.

Banzhaf III, J. F. (1968). One Man? Votes: Mathematical Analysis of Voting Power and Effective Representation. The George Washington Law Review, 36, 808-823.

Bergman, T. (1995). Constitutional Rules and Party Goals in Coalition Formation. An Analysis of Winning Minority Governments in Sweden. Umeå: Umeå University.

Dahl, R. A. (1957). The Concept of Power. Behavioural Science, 2, 201-215. https://doi.org/10.1002/bs.3830020303

De Swaan, A. (1973). Coalition Theories and Cabinet Formations. A Study of Formal Theories of Coalition Formation Applied to Nine European Parliaments after 1918. Amsterdam: Elsevier.

Downs, A. (1968). Ökonomische Theorie der Demokratie. Tübingen: J.C.B. Mohr (Paul Siebeck).

Fara, R., Leech, D., \& Salles, M. (eds.) (2014). Voting Power and Procedures. Essays in Honour of Dan Felsenthal and Moshé Machover. Berlin: Springer.

Felsenthal, D. S., \& Machover, M. (1998). The Measurement of Voting Power. Theory and Practice, Problems and Paradoxes. Cheltenham: Edward Elgar. https://doi.org/10.4337/9781840647761 
Felsenthal, D. S., \& Machover, M. (2005). Voting Power Measurement: A Story of Misreinvention. Social Choice and Welfare, 25, 485-506. https://doi.org/10.1007/s00355-005-0015-9

Holler, M., \& Illing, G. (2006). Einführung in die Spieltheorie. Berlin/Heidelberg/New York: Springer.

Holler, M., \& Owen, G. (eds.). (2001). Power Indices and Coalition Formation. Boston/Dordrecht/London: Kluwer Academic Publishers. https://doi.org/10.1007/978-1-4757-6221-1

Katz, R. S., \& Mair, P. (1995). Changing Models of Party Organization and Party Democracy. The Emergence of the Cartel Party. Party Politics, 1, 5-28. https://doi.org/10.1177/1354068895001001001

Keman, H. (1994). The Search for the Centre: Pivot Parties in West European Party Systems. West European Politics, 17, 124-148. https://doi.org/10.1080/01402389408425046

Kierchheimer, O. (1965). Der Wandel des westdeutschen Parteiensystems. PVS, 6, 12-40.

Korte, K.-R., \& Fröhlich, M. (2004). Politik und Regieren in Deutschland. Strukturen, Prozesse, Entscheidungen. In Paderborn et al. (Eds.), Ferdinand Schöningh.

Laver, M. (1998). Models of Government Formation. Annual Review of Political Science, 1, 1-25. https://doi.org/10.1146/annurev.polisci.1.1.1

Leech, D. (2002). Computation of Power Indices. Warwick Economic Research Papers No. 644, Warwick: The University of Warwick.

Leech, D. (2012). Computer Algorithms for Voting Power Analysis. http://homepages.warwick.ac.uk/ ecaae/\#Progam_List

Lewin, L. (1998). Majoritarian and Consensus Democracy: The Swedish Experience. Scandinavian Political Studies, 21, 195-206.

Lijphart, A. (2012). Patterns of Democracy. Government Forms and Performance in Thirty-Six Countries. New Haven, CT: Yale U.P.

Lipset, S., \& Rokkan, S. (1967). Cleavages Structures, Party Systems, and Voter Alignments: An Introduction. In S. Lipset, \& S. Rokkan (Eds.), Party Systems and Voter Alignments: Cross-National Perspectives (pp. 1-64). New York, NY: The Free Press.

Michels, R. (1962). Political Parties: A Sociological Study of the Oligarchical Tendencies of Modern Democracy. New York, NY/London: Free Press.

Naess, A. (1956). Democracy, Ideology and Objectivity: Studies in the Semantics and Cognitive Analysis of Ideological Controversy (Norwegian Research Council for Science Publications; Group Social Science; B308; 1).

Pelinka, A. (2002). Die FPÖ in der vergleichenden Parteienforschung. Zur typologischen Einordnung der Freiheitlichen Partei Österreichs. ÖZP, 31, 281-290.

Pelinka, A. (2004). Das politische System Österreichs. In I. Wolfgang (Ed.), Die politischen Systeme Westeuropas. Wiesbaden: VS-Verlag.

Pennings, P., Keman, H., \& Woldendorp (2006). Doing Research in Political Science (2nd ed.).

Poguntke, T. (1999). Winner Takes All: The FDP in 1982-1983: Maximizing Votes, Office, and Policy? In W. C. Müller, \& K. Strøm (Eds.), Policy, Office or Votes? How Political Parties in Western Europe Make Hard Decisions (pp. 216-236). Cambridge: Cambridge UP. https://doi.org/10.1017/CBO9780511625695.009

Riker, W. H. (1962). The Theory of Political Coalitions. New Haven, CT and London: Yale UP.

Rudzio, W. (2011). Das politische System der Bundesrepublik Deutschland. Wiesbaden: 
VS Verlag.

Sartori, G. (1976). Parties and Party Systems. A Framework for Analysis. Cambridge: Cambridge UP.

Schmidt, M. (2003). Political Institutions in the Federal Republic of Germany. OUP.

Schmidt, M. (2005). Das politische System der Bundesrepublik Deutschland. Munich: C.H. Beck.

Schmidt, M. G. (1996). Germany. The Grand Coalition State. In J. M. Colomer (Ed.), Political Institutions in Europe (pp. 62-98). London/New York, NY: Routledge.

Shapley, L. S., \& Shubik, M. (1954). A Method for Evaluating the Distribution of Power in a Committee System. The American Political Science Review, 48, 787-792. https://doi.org/10.2307/1951053

Shepsle, K. A. (2003). Perspectives on Politics. American Political Science Association, 1, 307-315.

Siaroff, A. (1999). Corporatism in 24 Industrial Democracies: Meaning and Measurement. European Journal of Political Research, 36, 175-205. https://doi.org/10.1111/1475-6765.00467

Vatter, A. (2009). Patterns of Democracy: A Sub-National Analysis of the German Länder. Acta Politica, 44, 410-438.

Weber, M. (1919). Politik als Beruf. München und Leipzig: Duncker \& Humblot.

Weber, M. (1978). Economy and Society. Berkeley, CA: University of California Press.

Weber, M. (2012). Gesammelte Politische Schriften Taschenbuch: Salzwasser Verlag. 


\section{Appendix}

A player's power index can be described as follows:

$$
\beta_{i}=\frac{\text { number of swings of a player } i}{\text { total number of coalitions which do not include the player } i}
$$

or in a formula

$$
\beta_{i}=\frac{\eta_{i}}{2^{n-1}}
$$

In order to measure relative voting power among players the total number of swings for all players is used as the denominator:

$$
\beta_{i}^{\prime}=\frac{\eta_{i}}{\sum \eta_{i}}
$$

Thus, the Banzhaf voting power index (Banzhaf, 1965) models the marginal contribution of a player to the success of a coalition, given a social choice mechanism. Looking here at the Banzhaf framework for solving N-person games, one starts from the characteristic function of a game by considering the set $2^{N}$ of all possible employing the assumption of equally likely coalitions. From these $2^{n}$ coalitions the Banzhaf score of player $i$ is calculated as the number of coalitions in which $i$ is critical, that is, the number of coalitions that player $i$ is able to swing. The Banzhaf power index of player $\beta_{i}$ is defined by the ratio of swings $\eta$ to coalitions. Thus, we have

$$
\beta_{i}=\frac{\eta_{i}}{2^{n-1}}
$$

The group capacity of arriving at a decision is the total winning coalitions of the game, $d$. Relating this group capacity to the total number of possible coalitions of a game we obtain $\delta$, the probability of decisiveness of a game,

$$
\delta=\frac{d}{2^{n}} .
$$

This parameter is much employed in order to understand the differences between the three basic voting schemes of a group: simple majority (SM), qualified majority (QM) and unanimity (veto). The number of individual swings, $\eta_{i}$ is another crucial parameter derived in this index. This parameter measures the number of swings a player can make, either swinging from YES to NO or from NO to YES, thereby altering the group outcome. The Banzhaf index relates this parameter to the total number of winning coalitions, $\mathrm{d}$, in order to obtain the individual probability of blocking of a player $i$. Thus, we arrive at another basic parameter:

$$
\theta_{i}=\frac{\eta_{i}}{d}
$$

The Banzhaf overall power index parameter can be factorised into the product of the probability of decisiveness, twice the individual probability of blocking, $\theta_{i}$. Thus, we have:

$$
\beta_{i}=2 \delta \theta_{i}
$$

